\title{
The effect of adding of tofu dregs flour on the physicochemical characteristics of shake flower cookies
}

\author{
Wayuni Rahmawany ${ }^{1}$, and Sentosa Ginting ${ }^{1, *}$ \\ ${ }^{1}$ Department of Food Science and Technology, Faculty of Agriculture, Universitas Sumatera Utara, \\ Jl. Dr. T. Mansur No.9, Medan 20222, North Sumatera, Indonesia
}

\begin{abstract}
The purpose of this study was to determine the effect of the addition of tofu dregs flour on the physicochemical characteristics of shake flower cookies. The analysis was carried out using a non-factorial completely randomized design with a ratio of tofu pulp flour: rice flour, namely $100 \%$ rice flour (control), 10\%: $90 \%, 20 \%: 80 \%, 30 \%: 70 \%, 40 \%$ : $60 \%, 50 \%: 50 \%$. Shake flower cookies significantly affects moisture content, crude fiber content, color hedonic value, taste, aroma, texture, and general acceptance. The shake flower cookies with the best treatment was found in the ratio of tofu dregs flour: rice flour (10\%: 90\%) and a total dietary fiber test was carried out.
\end{abstract}

\section{Introduction}

Indonesian people like soybeans because they provide many benefits so that the need for soybeans in Indonesia is large. Soybeans are widely used as raw materials for other preparations such as making tofu and tempeh because contain a fairly large protein, which is $36.49 \%$ in $100 \mathrm{~g}$ of soybeans [1]. Meanwhile, the tofu industry can produce a large amount of soybean waste because the manufacture of tofu only uses juice from soybeans. Therefore, the tofu processing waste, namely tofu dregs, can be reused into other raw materials [2].

Tofu dregs was the waste obtained when processing tofu which has a solid form [3]. The protein composition in tofu dregs is still quite large because at the time of processing tofu not all protein can be extracted [4]. Based on its nutritional content, tofu dregs can be used as a source of protein. Dried tofu dregs are more beneficial than wet tofu dregs because the moisture content in dry tofu dregs is low leading to a relatively long shelf life. The tofu dregs can be reused for processing into flour.

Tofu dregs flour is obtained from wet tofu dregs that have been dried and sifted until smooth [5]. In addition to having a large protein content, tofu dregs flour also has high enough fiber that can meet the fiber content need in our body. In the form of flour, tofu pulp has a long shelf life and further can be used as a mixture of foods such as cakes, biscuits, sticks and others.

\footnotetext{
* Corresponding author: sentosa.ginting@usu.ac.id
} 
One of the processed foods that can use tofu dregs flour is shake flower cookies. Shake flower cookies are a regional food in Indonesia. Shake flower cookies are often used as a snack for some people because it has a savory taste, therefore it can be combined with tofu dregs flour so that it can give a savory and sweet taste in the resulting shake flower cookies. Therefore can be increase selling value and composition nutrition of the cake.

\section{Materials and methods}

Tofu dregs are obtained from processed Tahu Sumedang Mas Kedo, which is located in Kelurahan Sari Rejo, Medan Polonia.

Tofu dregs flour is processed in the first way by washing the tofu dregs wet with water, after that it is pressed or filtered using a blanching filter cloth, until the moisture content is reduced. Furthermore, the tofu dregs weare steamed at a temperature of $100^{\circ} \mathrm{C}$ for 5 minutes, then the tofu dregs weare arranged on a baking sheet and heated in a drying oven at a temperature of $60^{\circ} \mathrm{C}$ for 6 hours to dry. After the tofu dregs were dried, the tofu dregs were crushed and sieved using an 80 mesh sieve.

Process shake flower cookies, namely flour pulp obtained previously mixed with rice flour in accordance with the ratio of flour tofu: rice flour that is $\mathrm{P}_{1}(0 \%: 100 \%), \mathrm{P}_{2}(10 \%$ : $90 \%), \mathrm{P}_{3}(20 \%: 80 \%), \mathrm{P}_{4}(30 \%: 70 \%), \mathrm{P}_{5}(40 \%: 60 \%)$ and $\mathrm{P}_{6}(50 \%: 50 \%)$. After that, add $35 \mathrm{~g}$ of sugar, $0.5 \mathrm{~g}$ of salt and $175 \mathrm{ml}$ of coconut milk to the dough and stir until not too thick and not too runny dough was formed. Heated oil and prepared the mold, after the hot oil was put in the mold into the oil and into the dough, after that put the mold in the oil again, while the mold was shaken until the dough was released from the mould, fried until a brown color, after that shake flower cookies were removed and drained. Stored for 2 days before testing. Analyzes were carried out on shake flower cookies in the such as moisture content, protein content, crude fiber content and organoleptic tests. Quality parameter analysis total dietary fiber was carried out for the best treatment.

\section{Results and discussion}

\subsection{Chemical analysis of flour raw materials}

Table 1. Chemical analysis of raw materials

\begin{tabular}{|l|c|c|}
\hline \multirow{2}{*}{ Parameter } & \multicolumn{2}{|c|}{ Raw materials } \\
\cline { 2 - 3 } & Tofu dregs flour & rice flour \\
\hline Moisture Content $(\% \mathrm{wb})$ & $8,46 \pm 0,33$ & $7,08 \pm 0,02$ \\
\hline Protein Content $(\% \mathrm{wb})$ & $16,32 \pm 0,13$ & $7,04 \pm 0,25$ \\
\hline Crude Fiber Content $(\% \mathrm{wb})$ & $2,68 \pm 0,02$ & $0,67 \pm 0,02$ \\
\hline
\end{tabular}

Note: data obtained from the average of 4 replications, $( \pm)$ indicates the standard deviation

\subsection{Moisture content}

The highest moisture content contained in $\mathrm{P}_{6}$ which is $3.83 \%$ and the moisture content was lowest for the $\mathrm{P}_{1}$ is $3.30 \%$ (Figure 1). This difference is due to the addition of tofu dregs flour in each treatment so that each treatment has an increase in moisture content. The moisture content of tofu dregs flour is also higher than that of rice flour (Table 1). In addition, the fiber content in flour can affect the water content because the fiber has the property of absorbing large amounts of water [6]. 


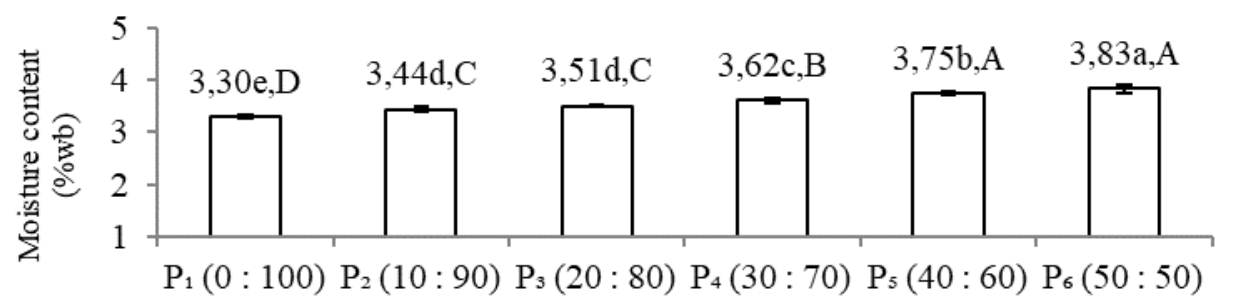

Comparison of Tofu Dregs Flour with Rice Flour (\%)

Fig. 1. The relationship between the addition of tofu dregs flour and the moisture content of shake flower cookies

\subsection{Protein content}

The highest protein content was at $\mathrm{P}_{6}(50 \%$ tofu dregs flour: $50 \%$ rice flour) which was $9.21 \%$ and the lowest protein content was at $\mathrm{P}_{1}$ (100\% rice flour) (Figure 2). This shows that with the addition of tofu dregs flour in each treatment, the protein content in shake flower cookies increase. This is because tofu dregs flour has a higher protein content than rice flour (Table 1). Tofu dregs flour has a large protein content because it comes from wet dregs produced from soybean juice during tofu processing [7].

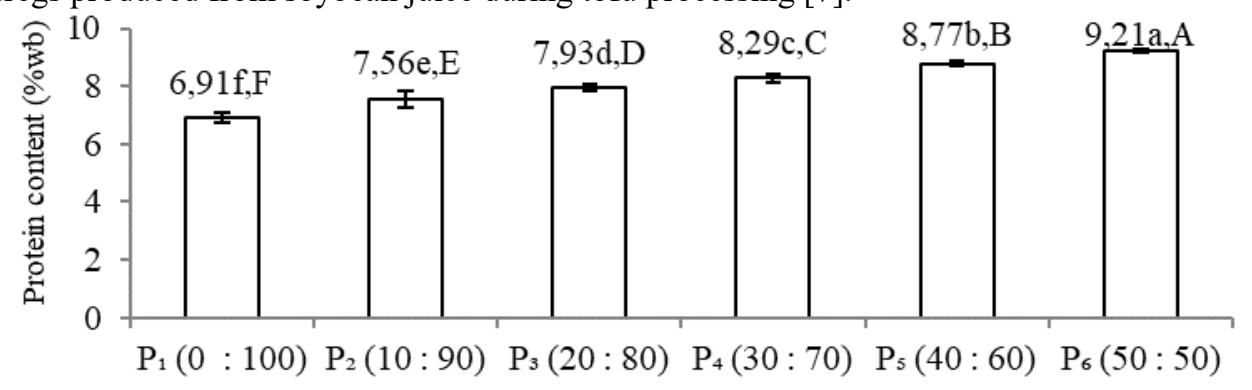

Comparison of Tofu Dregs Flour with Rice Flour (\%)

Fig. 2. The relationship between the addition of tofu dregs flour and the protein content of shake flower cookies

\subsection{Crude fiber content}

The highest crude fiber content in shake flower cookies was found at $\mathrm{P}_{6}$ (50\% tofu dregs flour: $50 \%$ rice flour) which was $2.29 \%$ and the lowest was at $\mathrm{P}_{1}(100 \%$ rice flour) which was $0.84 \%$ (Figure 3 ). In each treatment there was an increase in crude fiber content, this was due to the addition of tofu dregs flour in shake flower cookies. Tofu dregs flour has a higher fiber composition than rice flour. This is in accordance with the tests in rice flour and tofu dregs flour (Table 1). 


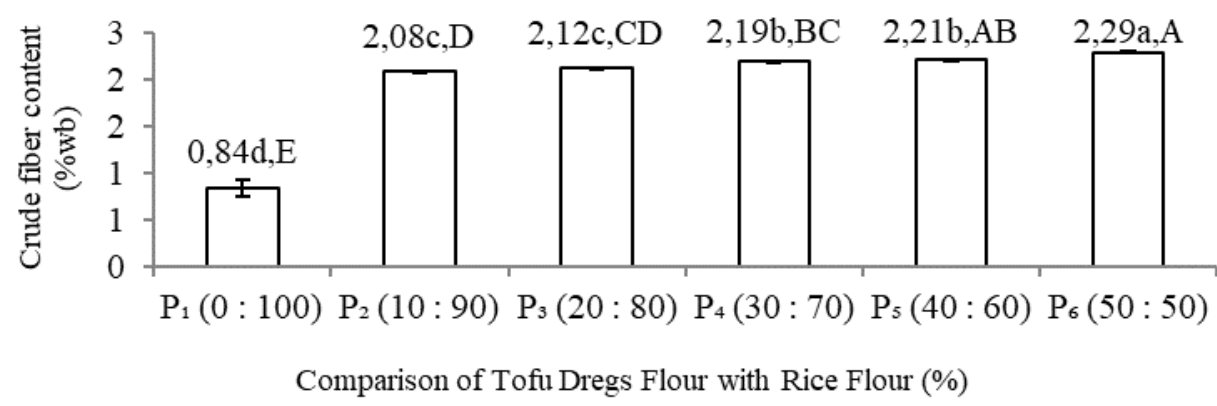

Fig. 3. The relationship between the addition of tofu dregs flour and the crude fiber content of shake flower cookies

\subsection{Color hedonic value}

The panelists liked the color of shake flower cookies at $\mathrm{P}_{1}(100 \%$ rice flour) with a hedonic value of 5.98 from level 1-7, compared to shake flower cookies at $\mathrm{P}_{6}(50 \%$ tofu dregs flour : $50 \%$ rice flour) which had the lowest color hedonic value is 5.24 (Figure 4). This shows that the addition of tofu dregs flour can produce a more brownish color that is less favored by the panelists. This can be influenced also because tofu dregs flour has a yellowish white flour color compared to rice flour which has a clean white color. The characteristic color of shake flower cookies favored by the panelists is golden yellow [8].

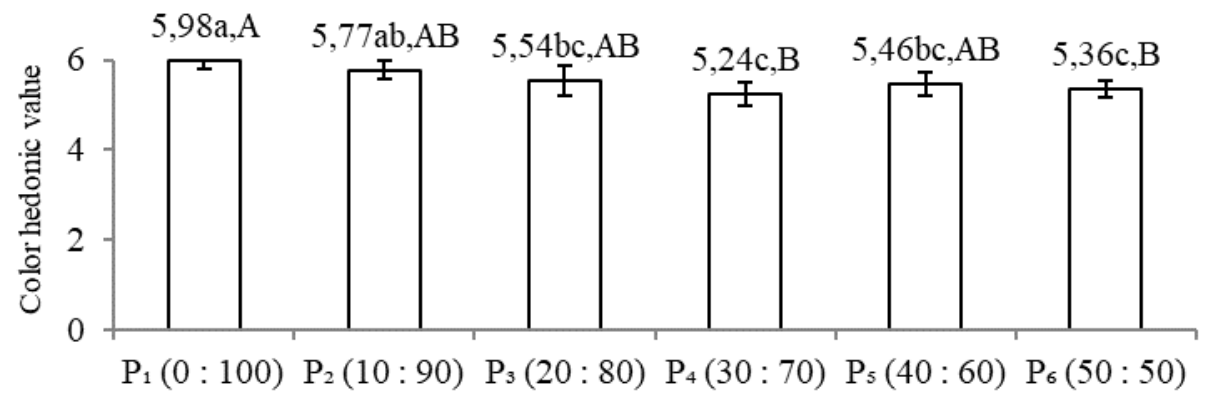

Comparison of Tofu Dregs Flour with Rice Flour (\%)

Fig. 4. The relationship between the addition of tofu dregs flour and the color hedonic value of shake flower cookies

\subsection{Aroma hedonic value}

Panelists liked the aroma of shake flower cookies at $\mathrm{P}_{1}(100 \%$ rice flour) with a hedonic value of 5.38 from levels $1-7$, compared to $\mathrm{P}_{6}(50 \%$ tofu dregs flour : $50 \%$ rice flour) which had a hedonic value of color the lowest is 5.31 (Figure 5). The addition of tofu dregs flour in each treatment causes the cake to have an unpleasant odor so that it is less liked by the panelists. The unpleasant odor produced by soybeans can be caused by lipoxygenase compounds [9]. 


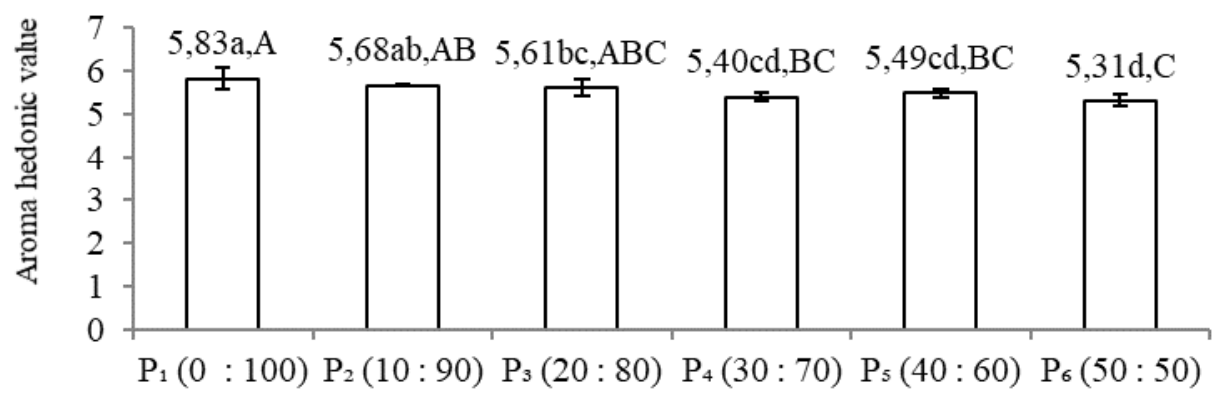

Comparison of Tofu Dregs Flour with Rice Flour (\%)

Fig. 5. The relationship between the addition of tofu dregs flour and the aroma hedonic value of shake flower cookies

\subsection{Taste hedonic value}

Taste hedonic value on shake flower cookies highest in $\mathrm{P}_{2}$ (10\% starch pulp out: $90 \%$ rice flour), namely 5.94 from levels 1-7 which means preferred by the panelists, due to the addition of flour tofu as much as $10 \%$ so that it can give a sweet and slightly savory taste to shake flower cookies (Figure 6). While the lowest taste hedonic value was found at $\mathrm{P}_{6}(50 \%$ tofu dregs flour: $50 \%$ rice flour) which was 5.24 from level 1-7. The addition of tofu dregs flour which is increasing in each treatment can produce an unpleasant taste and the more taste of tofu dregs is therefore less favored by the panelists.

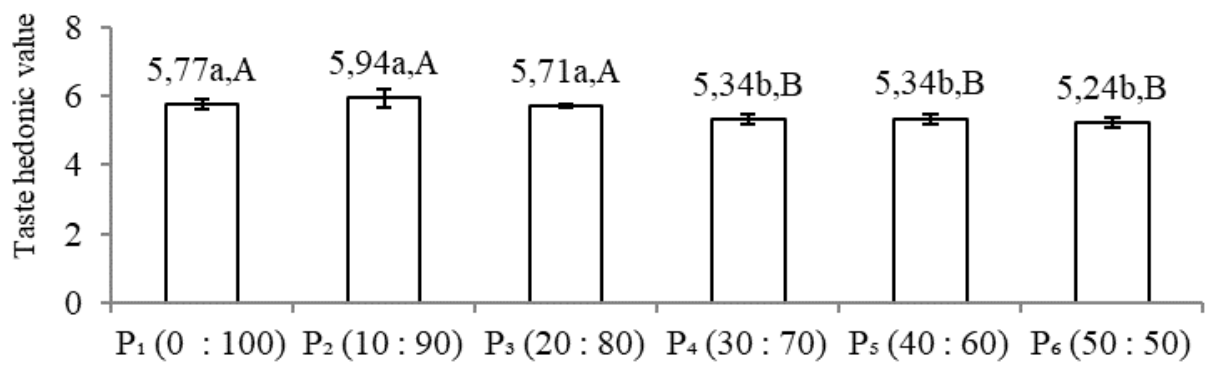

Comparison of Tofu Dregs Flour and Rice Flour (\%)

Fig. 6. The relationship between the addition of tofu dregs flour and the taste hedonic value of shake flower cookies

\subsection{Texture hedonic value}

Panelists liked the texture of shake flower cookies at $\mathrm{P}_{1}(100 \%$ rice flour) with a hedonic value of 5.99 from levels 1-7 which resulted in a crunchy texture on the cake, compared to $\mathrm{P}_{6}(50 \%$ tofu dregs flour : $50 \%$ rice flour) which had a value of the lowest hedonic texture is 5.07 (Figure 7). In each treatment there was a decrease in the hedonic value of the texture due to the addition of tofu dregs flour which is high in fiber and can affect the texture of shake flower cookies [9]. 


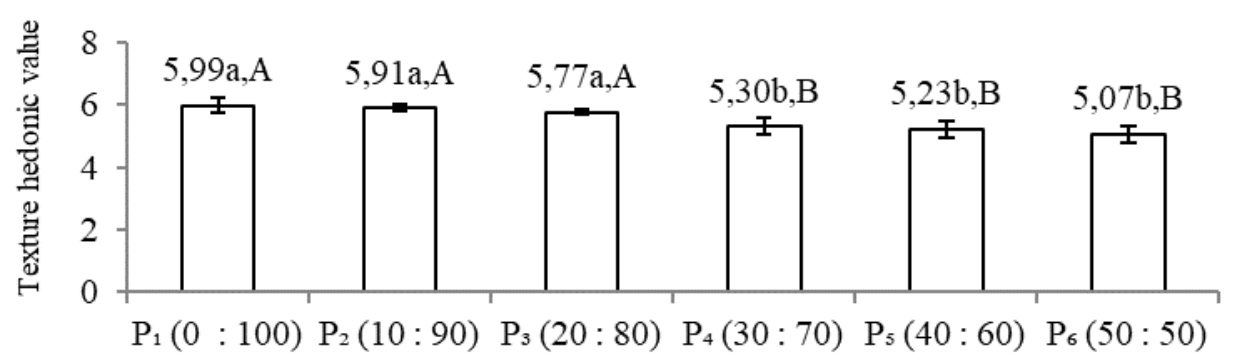

Comparison of Tofu Dregs Flour and Rice Flour (\%)

Fig. 7. The relationship between the addition of tofu dregs flour and the texture hedonic value of shake flower cookies

\subsection{General acceptance hedonic value}

The panelists did not like shake flower cookies with the addition of tofu dregs flour which was getting bigger because it produced a cake with a brownish color, unpleasant taste and aroma and a less crunchy texture. While shake flower cookies $\mathrm{P}_{2}$ is more preferred by the panelists and can be accepted by the panelists because it has a sweet taste and a slightly savory and has a crunchy texture (Figure 8).

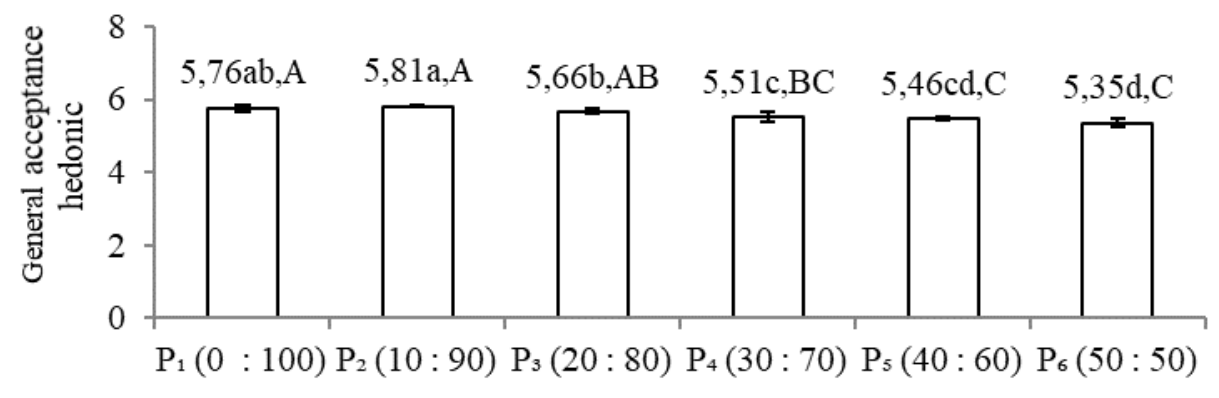

Comparison of Tofu Dregs Flour and Rice Flour (\%)

Fig. 8. The relationship between the addition of tofu dregs flour and the general acceptance hedonic value of shake flower cookies

\subsection{Dietary fiber content}

Based on the results of the test, it was found that $\mathrm{P}_{2}$ (10\% tofu dregs flour: $90 \%$ rice flour) was the best treatment. In (Figure 9) shows that the dietary fiber content in $\mathrm{P}_{2}$ is higher than $\mathrm{P}_{1}\left(100 \%\right.$ rice flour). This is due to the addition of tofu dregs flour at $\mathrm{P}_{2}$. According to research results [10], the content of dietary fiber in tofu dregs flour is higher, namely $66.60 \%$ in $100 \mathrm{~g}$, while rice flour has a dietary fiber content of $1.225 \%$ [11], so that the more addition of tofu dregs flour the content of dietary fiber on shake flower cookies is increasing. 


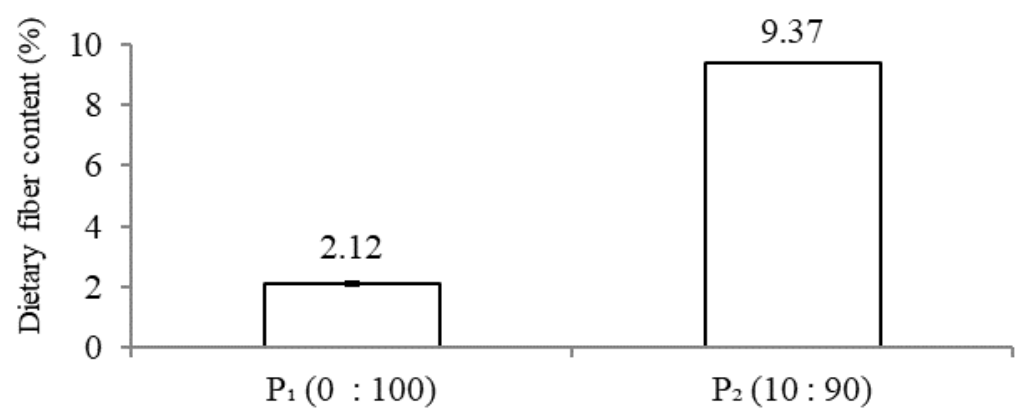

Comparison of Tofu Dregs Flour and Rice Flour (\%)

Fig. 9. The relationship between the addition of tofu dregs flour and dietary fiber content of shake flower cookies

\section{Conclusions}

The addition of tofu dregs flour has a very significant effect on moisture content, protein content, crude fiber content, hedonic value of taste, aroma, taste, texture and general acceptance. And the best treatment was obtained at $\mathrm{P}_{2}(10 \%$ tofu dregs flour: $90 \%$ rice flour) to be continued with the dietary fiber test.

For suggestions, further research is recommended to find out the proper storage of the cake to make it more durable and further research is needed to use tofu dregs flour for other food preparations.

\section{References}

1. N. Andarwulan, L. Nuraida, D.R. Adawiyah, R.N. Triana, D. Agustin, D. Gitapratiwi, Jurnal Mutu Pangan 5, 66-72 (2018)

2. T. Ramdhan, S. Aminah, U. Sente, A.W. Permana, Y. Handayani. Kelayakan ampas tahu sebagai bahan baku pangan berdasarkan karakteristik fisik, kimia, dan mikrobiologi. Prosiding Seminar Hasil Penelitian Tanaman Aneka Kacang dan Umbi (2015)

3. Herlinae, Yemima, G. Priyono, Jurnal Ilmu Hewani Tropika 6(1), $42-46$ (2017)

4. Tim Fatameta IPB. Pembuatan Kecap Ampas Tahu. Makalah. Dalam : Seminar Akademik di Bogor, 17 Desember (1981)

5. I. Marizalni. Subtitusi Tepung Ampas Tahu Pada Kualitas Cookies [Skripsi]. Padang : Fakultas Teknik, Universitas Negeri Padang (2013)

6. A. Kaahoao, N. Herawati, D.F. Ayu, Jurnal Faperta 4(2), 1-15 (2017)

7. B. Rusdi, I.T. Maulana, R.A. Kodir. Analisis kualitas tepung ampas tahu 2(1), 133-140 (2011)

8.. A. Suciati, D. Kristiastuti, E journal Boga 3(3), 1-7 (2014)

9. A. Fransiska, D. Rachmawanti, C. Anam, Jurnal Teknologi Pangan 8(2), 171-179 (2017)

10. C. Tu, S. Zhang, Q. Zhang, Y. Xiao, G. Xing, H. Xia, M. Dong, Peer Journal Preprints, (1), 1-28 (2016)

11. A. Febriani, D. Rachmawanti, C. Anam, Jurnal Teknosains Pangan 3(2), 28-38 (2014) 